膵頭部領域癌に括ける治癒切除後再発症例の臨床病理学的検討

$$
\text { 神戸大学第 } 1 \text { 外科（主任：斎藤洋一教授） }
$$

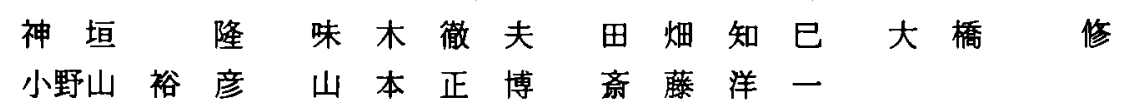

膵頭部領域癌の肉眼的治癁切除症例57例のらち再発様式が確認された23例を対象に肝 転移再発の有無により病理学的進展因子, Stage および得後生存期間を比較検討した。脺 頭部癌の肝転移再発例では $\mathrm{t} 3$ 3 $66.7 \%, \mathrm{y} 2, \mathrm{v} 2$ 以上がともに $100 \%$ を占め, 畽場径の大 きな例や高度脈管侵襲例が多かった。下部胆管癌中乳頭部癌では肝転移再発と病理学的 進展因子の間に関連を認めなかった，再発症例において低分化腺癌の 4 例は全例, 肝転 移再発をきたした。脺頭部癌再発例には進行例が多かった (Stage III 44.4\%, Stage IV $33.3 \%$ ）が，肝転移再発と Stageの間には関連を認めなかった，下部胆管癌では肝転移 再発例の全例が, 乳頭部癌では肝転移再発例の $50.0 \% か ゙$ Stage III 以上で, 進行した例が 多かった。膆頭部領域癌では肝転移再発例は肝転移再発を認めなかった例にくらべ術後 生存期間が短く，肝転移は予後を左右する再発様式と考えられた。

臬引用語：膵頭部領域癌，肝転移再発

\section{緒言}

近年, 術前診断の進歩と手術手技の向上により膵頭 部領域虎の切除例は増加しているものの, 他の消化器 癌にくらべるとその治療成績は依然として満足できる ものではない，脺頭部領域癌のなかです膵頭部癌は進 行例が多く，切除例です大部分は再発をきたし1，その 予後は不良である21ー4)。また，下部胆管癌においても進 行例では膵頭部癌と同様に予後不良である5). 乳頭部 癌は予後が最す良く外科的治療に適しているもの の6), 切除後の再発例も少なからず認められる7!。そこ で今回，われわれは教室の膵頭部領域癌について治㾏 切除後の再発様式を検索し, 膵頭部領域癌再発症例の 病理学的進展因子と術後生存期間について検討した。

\section{対象およU方法}

1980年 1 月から1992年12月までの 12 年間に神戸大学 第 1 外科にて䅅験した膵頭部領域癌は125例で，その内 訳は堭胞腺癌㧍よび粘液産生膵癌を除く膵頭部膵管癌 (以下，膵頭部癌と略す)72例, 下部胆管癌17例, 乳頭 部癌36例であった。切除例（率）はそれぞれ25例 (34.7\%)，15例 (88.2\%)，29例 (80.6\%)であり，治 意切除例（率）は18例 $(25.0 \%) ， 12$ 例 $(70.6 \%), 27$

1992年10月14日受付 1993年 4 月 6 日採用
表 1 腆頭部領城西の外科治痖

\begin{tabular}{|c|c|c|c|}
\hline & $\begin{array}{c}\text { 笛頭部病 } \\
(n=72)\end{array}$ & $\begin{array}{c}\text { 下部胆管禹 } \\
(n=17)\end{array}$ & $\begin{array}{l}\text { 乳頭部億 } \\
(n=36)\end{array}$ \\
\hline 切除 & $25(34.7 \%)$ & $15(88.2 \%)$ & $29(80.6 \%)$ \\
\hline 治密切除(事) & $18(25.0 \%)$ & $12(70.6 \%)$ & $27(75.0 \%)$ \\
\hline
\end{tabular}

例 (75.0\%)であった（表 1$)$.

今回, これら肉眼的治疾切除例57例を対象に再発様 式を retrospective に検索し, 再発症例を肝転移再発 を認めた例（以下，肝転移 (十) 例と略寸）之肝転移 再発を認めなかった例 (以下, 肝転移 (一) 例と略す) に分類し，肝転移再発の有無により手術時病理学的進 展因子, 肉眼的進行度および術後生存期間について比 較検討した。なお，再発様式は剖検あるいは再発時の 臨床所見, 画像診断にて決定し, 病理学的進展因子, 肉眼的進行度は腈癌取扱い規約息および胆道癌取扱い 規約”に準じた，有意差検定は $\mathrm{t}$ 㭘定あるいは $\boldsymbol{x}^{2}$ 検定 を用い, $\mathrm{p}<0.05$ を有意差ありとした。

$$
\text { 結果 }
$$

1. 切除術式

膵頭部領域癌治瘾切除例57例の手術術式は腈頭部癌 では脺頭十二指腸切除術 (以下, PD と略す) 7 例, 膵 


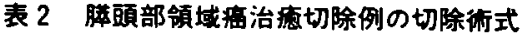

\begin{tabular}{|c|c|c|c|}
\hline & $\begin{array}{c}\text { 筷頭暗漓 } \\
(\mathrm{n}=18)\end{array}$ & $\begin{array}{c}\text { 下部胆管我 } \\
(\mathrm{n}=12)\end{array}$ & $\begin{array}{l}\text { 乳面部我 } \\
(n=27)\end{array}$ \\
\hline PD & 7 & 10 & 26 \\
\hline TP & $11(6)$ & 2 & 1 \\
\hline R1 & 10 & 1 & 3 \\
\hline R2 & 8 & 11 & 19 \\
\hline R3 & 0 & 0 & 5 \\
\hline
\end{tabular}

表 3 再発倳式

\begin{tabular}{|c|c|c|c|}
\hline & 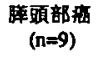 & $\begin{array}{c}\text { 下部胆管衫 } \\
(n=5)\end{array}$ &  \\
\hline 肝転移 & 3 & 3 & 4 \\
\hline 局所再発 & 6 & 1 & 0 \\
\hline リンバ節転移 & 5 & 1 & 5 \\
\hline 腹䐜枟移 & 2 & 1 & 0 \\
\hline 遠滑枟移 & 1 & 0 & 1 \\
\hline
\end{tabular}

全摘術(以下，TPと略す)11例で，下部胆管癌では PD 10例, TP 2 例, 乳頭部癌では PD 26例, TP 1 例であっ た。閁脈合併切除は膵頭部癌 6 例に施行され全例 TP 例であった。 またりンバ節郭清の程度別にみると膵頭 部癌 8 例, 下部胆管癌 11 例, 乳頭部癌 24 例に R2以上の 郭清が施行された（表 2 ）。

\section{2. 再発様式}

膵頭部領域癌治虑切除57例で再発様式が娭索しえた のは脺頭部癌 9 例，下部胆管癌 5 例，乳頭部癌 9 例の 計23例であった。肝転移再発をきたしたのは，膵頭部 癌 3 例 (33.3\%), 下部胆管癌 3 例 $(60.0 \%)$, 乳頭部 癌 4 例 (44.4\%) であった。 その他の再発様式として は，膵頭部癌では局所再発 6 例，腹膜転移 2 例，リン 八節転移 5 例，皮庙転移 1 例であった。 また下部胆管 癌では局所再発 1 例，腹膜転移 1 例，リンバ節転移 1 例で，乳頭部癌ではリンパ節転移 5 例，肺転移 1 例で あった（表 3 )。

\section{3. 病理学的進展因子の検討}

1) 脺頭部癌

再発症例 9 例の検討において, 腫瘍径は肝転移 $(+)$ 例では $\mathrm{t} 3$ 以上が 2 例 $(66.7 \%)$ を占め, $\mathrm{t} 2$ は 1 例 （33.3\%）にすぎなかった。一方，肝転移（一）例では $\mathrm{t} 2$ が 5 例 $(83.3 \%)$ と大部分を占めていた。組織型では 明らかな差を認めなかったか，低分化腺癌(以下，por と略す）の1例は旰転移再発をきたした。 また間質の 量比, INFでは明らかな差はなかった（表 4).
表 4 膵頭部宽再発症例

\begin{tabular}{|c|c|c|c|c|c|c|}
\hline 年祒 & 性別 & $\mathrm{t}$ & 組權 & 間负 & INF & 肝轱移再羿 \\
\hline 46 & $\mathbf{M}$ & 2 & tubl & scirth & $\beta$ & + \\
\hline 67 & $\mathbf{M}$ & 3 & tub2 & intermed & $\gamma$ & + \\
\hline 64 & $\mathbf{M}$ & 4 & por & med & $\beta$ & + \\
\hline 72 & $\mathbf{M}$ & 2 & tub1 & intermed & $\beta$ & - \\
\hline 54 & $\mathbf{F}$ & 2 & pap & intermed & $a$ & - \\
\hline 59 & $\mathbf{M}$ & 2 & ub2 & intermed & $\beta$ & - \\
\hline 65 & $\mathbf{M}$ & 2 & tubl & scirh & $\beta$ & - \\
\hline 68 & $\mathbf{M}$ & 2 & aub2 & intermed & $\beta$ & - \\
\hline 62 & $\mathbf{F}$ & 3 & adenosquam & intermed & $\gamma$ & - \\
\hline
\end{tabular}

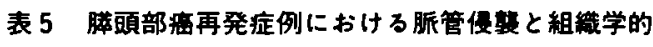
リンパ官転移

\begin{tabular}{|c|c|c|}
\hline & $\begin{array}{c}\text { 形坛移 }(+) \\
(n=3)\end{array}$ &  \\
\hline ly 0 & $0 \quad(0 \%)$ & $1(16.79)$ \\
\hline 1 & $0 \quad(0 \%)$ & $4(66.6 \%)$ \\
\hline 2 & $2(66.7 \%)$ & $1(16.7 \%)$ \\
\hline 3 & $1(33.3 \%)$ & $0 \quad(0 \%)$ \\
\hline vo & $0 \quad(0 \%)$ & $2(33.3 \%)$ \\
\hline 1 & $0 \quad(0 \%)$ & $4(66.6 \%)$ \\
\hline 2 & $3(100 \%)$ & $0 \quad(0 \%)$ \\
\hline no & $2(66.7 \%)$ & $1(16.7 \%)$ \\
\hline 1 & $0 \quad(0 \%)$ & $4(66.6 \%)$ \\
\hline 不明 & $1(33.3 \%)$ & $1(16,7 \%)$ \\
\hline
\end{tabular}

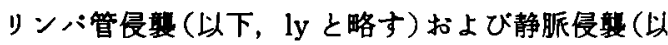
下，v と略す)ではly2，v2以上の高度脈管侵襲が肝転 移（+）例ではそれぞれ 3 例 $(100 \%) ， 3$ 例 (100\%) に認められたのに対し肝転移（一）例ではそれぞれ1 例 (16.6\%)，0例 (0\%) に認められたにすぎなかっ た $(\mathrm{p}<0.05)$ ．リンバ節転移（以下， $\mathrm{n}$ 之略す）では $\mathrm{n}$ 陽性の 4 例はすべて肝転移（一）例であった（表 5 ).

2）下部胆管癌

再発症例 5 例において, 組織型が por の 2 例は全 例，肝転移(十)例であった， ly, v, 十二指腸浸潤(以 下，d と略す），膵蔵浸潤(以下，panc と略す）および $\mathrm{n}$ に関して肝転移再発の有無に上る明らかな差はな かったが， d 陽性の 2 例および n 陽性の 1 例は肝転移 （+）例であった。 また pancでは肝転移（十）例の2 例と旰転移（一）例の 1 例が panc 3であった（表6）.

3）乳頭部癌

再発症例 9 例において，組織型は乳頭腺癌が 5 例 （55.6\%）と半数以上を占めていたが, porの 1 例は肝 転移(十)例であった. ly については肝転移 $(+),(-)$ 例ともに全例，ly 陽性であった。 $\mathrm{v}$ 陽性は肝転移 $(+)$ 例では 3 例 $(60.0 \%)$ ，肝転移(一)例では 1 例 $(20.0 \%)$ 
表 6 下部胆管莣再発症例

\begin{tabular}{|c|c|c|c|c|c|c|c|c|}
\hline 年撂 & 性別 & 整绩 & ly & $\mathbf{v}$ & panc & $d$ & $n$ &  \\
\hline 68 & $\mathbf{M}$ & tubl & 2 & 1 & 3 & 0 & 1 & + \\
\hline 71 & $\mathbf{M}$ & por & 1 & 0 & 3 & 3 & 0 & + \\
\hline 66 & $F$ & por & 1 & 1 & 0 & 2 & 0 & + \\
\hline 49 & $\mathbf{M}$ & pap & 1 & 3 & 3 & 0 & 0 & - \\
\hline 63 & $\mathbf{F}$ & tubl & 2 & 2 & 0 & 0 & 0 & - \\
\hline
\end{tabular}

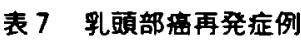

\begin{tabular}{|c|c|c|c|c|c|}
\hline 年蛅 & 性别 & 組䌯 & ly & $\mathbf{v}$ & 肝枟移再発 \\
\hline 45 & M & pap & 3 & 0 & + \\
\hline 68 & M & tubl & 3 & 1 & + \\
\hline 70 & $\mathbf{M}$ & pap & 2 & 2 & + \\
\hline 73 & M & por & 2 & 1 & + \\
\hline 74 & M & tabl & 2 & 0 & - \\
\hline 71 & F & pap & 3 & 2 & - \\
\hline 51 & $\mathbf{M}$ & tubl & 2 & 0 & - \\
\hline 44 & $F$ & pap & 2 & 0 & - \\
\hline 56 & $\mathrm{~F}$ & pap & 1 & 0 & - \\
\hline
\end{tabular}

と差を認めるものの明らかな有意差はなかった（表 $7)$.

panc 陽性は肝転移 $(+)$ 例では 2 例 $(50.0 \%)$, 肝転 移 (一) 例では 1 例 $(20.0 \%) て ゙ ， \mathrm{~d}$ 陽性は肝転移 (+) 例では 4 例 $(100 \%)$, 肝転移 (一) 例では 2 例 $(40.0 \%)$ と panc，dともに肝転移（+）例に陽性例が多かった るのの明らかな差は認めなかった。 n陽性は肝転移 (+) 例では 2 例 $(50.0 \%)$, 肝転移 (一) 例では 3 例 （60.0\%）と差はなかった（表 8 ).

\section{4. 肉眼的進行度}

肉眼的進行度 (以下, Stage と略す) を検討すると， 膵頭部癌では肝転移 $(+)$ 例は Stage II 1 例 (33.3\%)， Stage III 1 例 $(33.3 \%)$, Stage IV 1 例 (33.3\%) て 肝転移 (一) 例では Stage II 1 例 (16.7\%), Stage III 3 例 $(50.0 \%)$, Stage IV 2 例 $(33.3 \%)$ と肝転移再 発と Stageの間に関連を認めなかった。しかし，下部 胆管癌においては肝転移 (一) 例の 2 例は Stage II で あったのに対し, 肝転移（+）例ではStage III 1 例

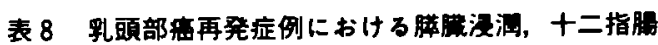
漫洞书よび組满学的リンパ節転移

\begin{tabular}{|c|c|c|}
\hline & $\underset{(n=4)}{\text { 肝轻移 }(+)}$ & $\begin{array}{c}\text { 肝敕移 ( ( ) } \\
(n=5)\end{array}$ \\
\hline panc 0 & $2(50.0 \%)$ & $4(80.0 \%)$ \\
\hline 1 & $1(25.0 \%)$ & $1(20.0 \%)$ \\
\hline 2 & $1(25.0 \%)$ & $0 \quad(0 \%)$ \\
\hline do & $0 \quad(0 \%)$ & $3(60.0 \%)$ \\
\hline 1 & $0 \quad(0 x)$ & $0 \quad(0 \%)$ \\
\hline 2 & $3(75.0 \%)$ & $1(20.0 \%)$ \\
\hline 3 & $1(25.0 \%)$ & $1(20.0 \%)$ \\
\hline no & $2(50.0 \%)$ & $2(40.0 \%)$ \\
\hline 1 & $2(50.0 \%)$ & $2(40.0 \%)$ \\
\hline 2 & $0 \quad(0 x)$ & $1(20.0 \%)$ \\
\hline
\end{tabular}

(33.3\%), Stage IV 2 例 (66.7\%) と Stage II は認め す進行例が多かった，乳頭部癌でも肝転移（一）例が Stage I 1 例 (20.0\%), Stage II 4 例 (80.0\%) であっ たのに対し，肝転移(十)例では Stage III が 2 例 （50.0\%）と半数を占め進行した症例が多かった（京 $9)$.

\section{5. 術後生存期间}

肝転移再発の有無によりそれぞれの術後平均生存期 間を比慗すると，脺頭部癌では肝転移 $(+)$ 例は 7.2 カ 月と肝転移(一)例の18.2力月にくらべ短い傾向にあっ た.下部胆管癌では肝転移 $(+)$ 例9.7カ月と肝転移 $(-)$ 例の35.9カ月にくらべ短かった。 さらに乳頭部癌です 肝転移 (+) 例は18.6力月と肝転移 (一) 例の33.5力 月にくらへ有意に短く $(\mathrm{p}<0.05)$, 膵頭部領域癌にお いては肝転移 $(+)$ 例は (-) 例にくらべ術後生存期 間が短かった（表10）.

\section{考 察}

膵頭部領域癌はその解剖学的特徽より周囲組織への 浸潤をきたしやすく多彩な進展様式を呈する(10)11， ま た切除後の再発様式す種々の再発か重複しており進展 因子や再発様式の解析は必ずしす容易ではない，そこ で膵頭部領域癌治缯切除例を対象に再発症例の病理学 的進展因子および術後生存期間を肝転移再発の有無に

表 9 内眼的進行度

\begin{tabular}{|c|c|c|c|c|c|c|}
\hline \multirow[b]{3}{*}{ Stage I } & \multicolumn{2}{|c|}{ 睡頭部畫 } & \multicolumn{2}{|c|}{ 下部胆菑清 } & \multicolumn{2}{|c|}{ 乳頍部薄 } \\
\hline & $\begin{array}{c}\text { 肝稳 }(+) \\
(n=3)\end{array}$ & $\begin{array}{c}\text { 肝舩移 ( } \\
(n=6)\end{array}$ & $\begin{array}{c}\text { 肝転移 }(+) \\
(n=3)\end{array}$ & $\begin{array}{c}\text { 肝枟和 }(-) \\
(n=2)\end{array}$ & 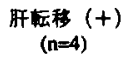 & $\begin{array}{c}\text { 胿枟 } \\
(n=5)\end{array}$ \\
\hline & $0 \quad(0 \%)$ & $0 \quad(0 \%)$ & $0 \quad(0 \%)$ & $0 \quad(0 \%)$ & $1(25.0 \%)$ & $1(20.0 \%)$ \\
\hline II & $1(33.0 \%)$ & $1(16.7 \%)$ & $0 \quad(0 \%)$ & $2(100 \%)$ & $1(25.0 \%)$ & $4(80.0 \%)$ \\
\hline III & $1(33.3 \%)$ & $3(50.0 \%)$ & $1(33.3 \%)$ & $0 \quad(0 \%)$ & $2(50.0 \%)$ & $0 \quad(0 \%)$ \\
\hline IV & $1(33.3 \%)$ & $2(33.3 \%)$ & $2(66.7 \%)$ & $0 \quad(0 \%)$ & $0 \quad(0 \%)$ & $0 \quad(0 \%)$ \\
\hline
\end{tabular}


表10 術後平均生存期间（月）

\begin{tabular}{|c|c|c|c|}
\hline & 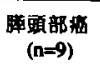 & $\begin{array}{c}\text { 下部胆管薷 } \\
(\mathrm{n}=5)\end{array}$ & $\begin{array}{c}\text { 记頭部鹤 } \\
(n=9)\end{array}$ \\
\hline 肝枟 $(+)$ & 7.2 & 9.7 & 18.6 \\
\hline 肝的 (-) & 18.2 & 35.9 & 33.5 \\
\hline
\end{tabular}

より比較し, 腈頭部領域癌の外科治療上の問題点につ いて検討した。

膵頭部領域癌の切除率は諸家の報告では，膵頭部癌 $\left.21.1 \% \sim 61.2 \%{ }^{121} \sim 14\right)$, 下部胆管癌 $61.4 \% \sim 100 \%{ }^{1516)}$, 乳頭部癌 $73.5 \%$ - 94.1\% ${ }^{677) 17}$ 之脺頭部癌の切除率が 最も低いとされている，自呀例においても膰頭部癌の 切除率は $34.7 \%$ と最も低率であった。

膡頭部領域癌の手術術式としてわれわれの教室では PD，R2以上の郭清を基本としているが，本検討におけ る膵頭部癌の TP 11例中 2 例は広範な膵漫潤をともな 5 術中迅速病理猃断の pw 陽性例であり，下部胆管癌， 乳頭部癌の TP 3 例は膵空腸䋖合不全例であった。

脺頭部癌の再発部位としては訮転移再発, 局所再発 が多く ${ }^{18)}$, 自鈋例でも局所再発が 6 例と最す多く，次い でリンバ節転移 5 例, 肝転移再発 3 例であった。病理 学的進展因子の検討では，膵癌では腫場径の増大とと すに肝転移率が増加し12)，苏頭部癌では $\mathrm{t} 3$ 例は $\mathrm{t} 1$ ， $\mathrm{t} 2$ 例にくらべ遠隔 (主に肝)再発死亡が多い(19)とされてい るが，今回の検討では，肝転移（+）例には循晹径の

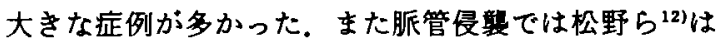
膆頭部領域癌のなかです膵頭部癌は静脈侵唯の頻度が 高く，訮転移率を高めると報告しており，われわれの

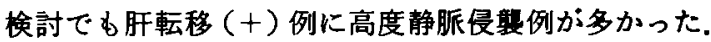
石川ら 199はn2例では $\mathrm{n} 0, \mathrm{n} 1$ 例にくらべ逗隔 (肝) 転移 で死亡する例が多かったとしているが，われわれの今 回の娭討では $\mathrm{n}$ 陽性と肝転移再発との関連は見いだ せなかった。

下部胆管癌の再発様式には肝転移再発が高率であっ たとする報告 ${ }^{20211}$ と局所再発が高率であったとする報 告5)15)があるが，自験例では肝転移再発が $60.0 \%(3 / 5)$ と最す高率であった。嶋田ら ${ }^{211}$ は中，下部胆管癌におい 乙肝転移再発は por 例や $\mathrm{n}$, panc, ly, v因子が高度な 例が多かったと述べている，われわれの検討では下部 胆管癌において肝転移再発之病理学的進展因子との間 に明らかな関連はなかったものの, por 例の 2 例は肝 転移再発をきたし， d, n 陽性例は全例，肝転移(十) 例であった。また自験例において局所再発は1例にす ぎなが，中，下部胆管癌では神経叢浸潤が局所再発


でなく神経噥郭清をす重視した術式が必要だと考克ら れている ${ }^{5222)}$.

乳頭部癌の再発様式として多くはリンハ節転移ある いは肝転移再発をきたすが尚5)，その再発様式の特徵 は腸間膜根部のリンバ節 (No. 14) 転移と考えられて おり ${ }^{723)}$ ，自験例においてもリンバ節転移例は全例， No. 14 リンパ節に転移を認めた。永川ら ${ }^{24} は$ 腸間膜根 部のリンハ節を重点的に郭清することにより 5 年生存 率が向上したと報告しており，腸間膜根部りンハ節の 重点的な郭清が重要であると考えられている7115244). 新 井田ら"は病理学的進展因子別の再発様式を梌討して おり，panc $1 \beta$ 以上では肝転移再発 $61.5 \%(8 / 13)$ ，リ ンパ節再発 $76.9 \%(10 / 13) ， \mathrm{~d}$ 陽性では両者とも100\% (13/13)，n 陽性ではそれぞれ92.3\%(12/13)，84.6\% (11/13）と報告している．われわれの検討では訮転移 再発 (+) 例に panc, $d$ 陽性がやや多かったものの肝 転移再発と病理学的進展因子の間に明らかな関連はな かった。

過去10年間の膵癌全国集計 ${ }^{25}$ の結果によると，膆癌 切除例 3 ，743例の5 5 Stage III 以上は2,640例 （70.5\%）と進行例が多くを占めているが， Stage I, II といった症例でも肝転移再発が報告されてい る4261. 自験例においてもその大部分は Stage の進行 した症例であったが，肝転移再発をきたした 3 例の5 ち 1 例が Stage II であり, 膆頭部癌では肝転移再発と Stageの間に関連を認めなかった。

嶋田ら ${ }^{211}$ は下部胆管癌切除例を検討し，肝，全身転移 例 4 例中, Stage III は 1 例, Stage IV は 3 例で, 局 所再発, 腹膜転移例 4 例中, Stage I は 1 例, Stage III は3 例と報告しており，われわれの検討でも肝転移 （+）例に進行例が多かった。

乳頭部癌では今泉ら 27 は 3 年以上生存後再発例を模 討し，肝転移再発をきたした 2 例の組織学的進行度（以 下, stage と略す) は stage II 1 例, stage IV 1 例で， リンバ節再発 5 例は stage II 2 例, stage III 2 例, stage IV 1 例であったと述べている. 自験例では肝転 移（一）５例は全例，Stage II 以下であったが，肝䢂 移（+）例では 4 例中 2 例が Stage III で進行例が多 かった.

術後平均生存期間では膵頭部癌においては松野ら は膵癌切除後の血行性転移の特徽は術後早期の肝転移 であると述へてており，三村ら゙す肝転移再発は術後早 期に発見されたと報告している，今回の検討では肝転 
移 (+) 例の術後生存期間は (一) 例にくらべ短く, 術後早期に肝転移再発が現れることを反映していると 考えられた。

下部胆管癌では嶋田ら ${ }^{211}$ は PD 後の肝, 全身転移例 の平均生存期間は19.2力月と報告しており，われわれ の挨討では肝転移 $(+)$ 例の術後生存期間は9.7カ月と (一) 例の35.9カ月にくらべ短かった。

乳頭部癌では再発様式別にみた新井田ら》の検討で は, 腸間膜根部リンパ節再発では24.4カ月, 肺, 肝, 骨転移では16.4カ月としており，今回の検討です肝転 移 $(+)$ 例の術後生存期間は（一）例にくらべ有意に 短かった。したがって，膵頭部領域癌に拈ける肝転移 再発は術後の生存期間を左右する再発様式の一つたと 考えられた。

\section{結語}

腈頭部領域癌の肉眼的治疾切除例57例を対象に再発 様式を retrospective に検索し，肝転移再発の有無に より病理学的進展因子, Stage 括よび術後生存期間を 比較検討した．その結果，脺頭部癌では肝転移再発例


管癌および乳頭部癌では肝転移再発例に Stage の進 行した例が多かった，再発症例に打いて por 例は全 例，肝転移再発をきたしたままた膵頭部領域癌では肝 転移再発例は肝転移再発を認めなかった例にくらべ術 後生存期間が短く，肝転移再発は術後生存期間を左右 する再発様式たと考えられた。

以上より，腈頭部領域癌治瘾切除例。特に進行例に 対しては肝転移再発予防のために術中，術後の強力な 補助療法が必要と考えられた。

\section{文献}

1) 井沢邦秀，土屋涼一：膵癌一外科療法一日臨 46 ： 651-655, 1988

2) Fortner JG: Regional pancreatectomy for cancer of the pancreas, ampulla and otherrelated sites. Tumor staging and results. Ann Surg $199: 418-425,1984$

3）中山和道, 津留昭雄：勝頭十二指腸切除例の治療 成績とその問題点，とくに乳頭部癌，下部胆管癌， 胼頭部癌について。，日消外会誌 $22: 2516-2520$, 1989

4）三村 久，森 雅信，浜崎啓介他：勝頭部癌に対す る Isolated Pancreatectomy一その手技と成績 一. 胆と腈 $12: 293-298,1991$

5) 中山和道, 有田佰彦, 木下 文他：中下部胆管癌の
治療成繢からみた払大手術の意義。日外会誌 91 ： 1245-1248, 1990

6）水本龍二，世古田枒：乳頭部癌の進展度と手術成 續。胆と猝 $5: 875-880,1984$

7）新井田達雄：十二指腸乳頭部癌の臨床病理学的研 究一予後規定因子と再発梯式について一。消外 会誌 22:2009-2017，1989

8）日本脺䁍学会編：外科·病理脺癌取扱い規約, 第 3 版，金原出版，東京， 1986

9）日本胆道外科研究会編：外科・病理胆道癌取扱い 規約，第 2 版，金原出版，東京， 1984

10) Cubilla AC, Fortner JG, Fitzgerald PJ : Lymph node involvement in carcinoma of the head of pancreas area. Cancer 41: 880-887, 1978

11) Nagai H, Kuroda A, Morikawa $Y$ : Lymphatic and local spread of $\mathrm{T} 1$ and $\mathrm{T} 2$ pancreas cancer : A study of autopsy material. Ann Surg $204: 65-71,1986$

12）松野正紀，加藤宣諴，中村隆司他：朣癌血行性転移 例の検討. 癌の臨 $31: 537-543,1985$

13）今泉陖秀，羽生富士夫, 吉川達雄：膵頭部密に対す る抬大手術の意義と限界。日外会誌 87：1173 $-1176,1986$

14）大山廉平：膵癌切除例の臨床病理学的研究一臨床 病理学的にみた予後左右およびリンバ節転移の模 討一。外会誌 $85: 820-834,1984$

15）竜 崇正, 山本義一, 小出義雄他：再発様式および 非治炭切除の要因からみた胆道癌外科治療の問題 点. 日消外会誌 $20: 1898-1904,1987$

16）松野正紀，鉿木正徳，大内清昭：病期·病龍加らみ

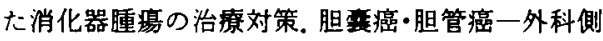
より一. 医と菜学 $22: 74-82,1989$

17）松野正紀，小針雅男，山内秀生他：十二指腸乳頭部 癌の外科治療。胆と膵 $5: 869-874,1984$

18）营原正都, 永川宅和, 上田順彦他：再発様式加右 た膆頭部㠊の手訹術式の検討。日消外会誌 21 ： $1277-1281,1988$

19）石川治, 大東弘明, 今岡真義他：膵頭部膵管癌に 対する払大手術の意義と適応。成人病 29：169 $-175,1989$

20）江口礼紀：胆管癌切除例の臨床病理学的検討。胆 道 $3: 46-56,1989$

21）嶋田 鉱，新本修一，泉 俊昌他：術後成績からみ た胆管癌治療上の問題点. 胆道 $5: 40-48,1991$

22）永川宅和，大田哲生：肝外胆道癌の進展様式につ 
いて. 胆と膵 $11: 333-338,1990$

23）米村 豊, 永川宅和，宮崎逸雄：羘頭部領域癌拡大 郭清術症例の検討ーリンバ節転移を中心K一，日 消外会誌 $15: 31-39,1982$

24）永川宅和：膡頭部領域癌に対与る拻大郭清術。外 科治療 $52: 189-196,1985$
25）日本勝眼学会編：全国墙癌登録集計一10年度分総 集計一. 1991

26）今泉俊秀, 羽生富士夫：膵頭部癌抎大手術の適応 と限界. 胆と膵 $7: 991-998,1986$

27）今泉俊秀, 新井田達雄, 羽生富士夫：釉頭部癌の外 科治療成嚗。消化器科 $8: 305-314,1988$

\title{
CLINICOPATHOLOGICAL STUDY OF RECURRENT CASES AFTER CURATIVE RESECTION IN CARCINOMAS OF PANCREATIC HEAD REGION
}

\author{
Takashi KAMIGAKI, Tetsuo AJIKI, Tomoki TABATA, Osamu OHASHI, Hirohiko ONOYAMA, \\ Masahiro YAMAMOTO and Yoichi SAITOH \\ First Department of Surgery, Kobe University School of Medicine
}

A total of 125 patients with carcinoma of the pancreatic head region was treated at the department, and 57 out of 125 patients underwent curative resection. Twenty-three of the 57 patients had recurrence of known pattern. In these 23 patients, pathological factors, clinical stage, and postoperative survival time were comparatively studied in terms of presence of hepatic metastasis. Among recurrent cases of cancer of the pancreatic head, $66.7 \%$ of them were more than $\mathrm{t} 3$, and all of them were more than ly2 and v2. Most tumors were large in size and had advanced vessel involvement. There were no significant correlation between hepatic recurrence and pathological factors in carcinomas of the lower bile duct and ampulla of Vater. Of these 23 recurrent cases, all 4 cases of poorly differentiated adenocarcinoma recurred in the liver. Most recurrent cases of carcinoma of the pancreatic head were in an advanced stage, $44.4 \%$ in Stage III and $33.3 \%$ in Stage IV. There were no significant differences between hepatic recurrence and stage. All cases of carcinoma of the lower bile duct with hepatic recurrence and $50 \%$ of those of ampullary carcinoma with hepatic recurrence were in Stage III 6r more. These findings indicated that most cases with hepatic recurrence were in advanced stage. Average postoperative survival time was short in cases with hepatic recurrence compared with those without hepatic recurrence as to carcinomas of the pancreatic head region. It is thought that metastasis to the liver might be a determinant factor for the prognosis. 